\title{
Analisis Guru dalam Menjaga Tata Kelola Pembelajaran Pendidikan Anak Usia Dini Selama Pandemi Covid-19
}

\author{
Maria Qori'ah $^{1}{ }^{\bowtie}$, Siti Masitoh ${ }^{2}$, Sri Setyowati ${ }^{3}$ \\ Pendidikan Dasar Konsentrasi PAUD, Univeristas Negeri Surabaya, Indonesia(1, 2, 3) \\ DOI: $\underline{10.31004 / \text { obsesi.v6i1.1453 }}$
}

\begin{abstract}
Abstrak
Penelitian untuk menganalisis guru dalam menjaga tata kelola pembelajaran pendidikan Anak Usia Dini Selama Pandemi Covid-19. Metode penelitian digunakan dalam penelitian adalah metode kualitatif deskriptif menggunakan pendekatan studi kasus. Subjek yang digunakan pada penelitian guru tiap dari lembaga sekolah yang berjumlah 18 guru di Kota Surabaya penentuan subjek berdasarkan pemilihan sekolah Taman Kanak-kanak yang hanya terakreditasi A. Teknik pengumpulan data berupa wawancara melalui whatsapp. Analisis data coding dan dideskripsikan secara narasi menggunakan koleksi data, reduksi data, penyajian data, penarikan kesimpulan. Hasil penelitian menunjukkan bahwa tata kelola perencanaan pada masa Pandemi Covid-19 rencana pembelajaran dinyatakan bahwa perencanaan pembelajaran anak usia dini meliputi perencanaan semester, rencana kegiatan mingguan (RKM), dan rencana kegiatan harian (RKH) dengan menggunakan kurikulum darurat. Tata kelola pelaksanaan pembelajaran menggunakan variasi blended learning dengan memadukan pembelajaran daring dan luring (home visit). Sedangkan untuk tata kelola evaluasi pembelajaran selama covid-19 dengan menggunakan penilaian fortopolio dan berbasis praktik secara online di rumah.
\end{abstract}

Kata Kunci: analisis guru; tata kelola pembelajaran paud, pandemi covid-19

\begin{abstract}
Research to analyze teachers in maintaining the governance of early childhood education learning during the Covid-19 pandemic. The research method used in this research is descriptive qualitative method using a case study approach. Subjects used in the teacher research from each school institution totaling 18 teachers in the city of Surabaya were determined based on the selection of kindergarten schools that were only accredited A. The data collection technique was in the form of interviews via whatsapp. Data analysis was coding and described in a narrative manner using data collection, data reduction, data presentation, and conclusion drawing. The results showed that planning governance during the Covid-19 Pandemic learning plan stated that early childhood learning planning included semester planning, weekly activity plans (RKM), and daily activity plans (RKH) using an emergency curriculum. The governance of the implementation of learning uses a variation of blended learning by combining online and offline learning (home visits). As for the management of learning evaluation during covid-19 using fortopolio assessment and practice-based online at home.
\end{abstract}

Keywords: teacher analysis ;ecd learning management, covid-19 pandemic

Copyright (c) 2021 Maria Qori'ah, Siti Masito, Sri Setyowati

$\triangle$ Corresponding author:

Email Address : maria.19026@mhs.unesa.ac.id (Surabaya, Jawa Timur, Indonesia)

Received 15 Januari 2021, Accepted 15 June 2021, Published 16 June 2021 


\section{PENDAHULUAN}

Saat ini di seluruh belahan dunia sedang mengalami fenomena pandemi COVID-19 atau dikenal juga dengan sebutan virus corona. Pandemi merupakan sebuah epidemi yang menyebar ke beberapa negara atau benua, dan pada umumnya menjangkiti banyak orang. Pada tanggal 11 Maret 2020, WHO menetapkan COVID-19 sebagai sebuah pandemi. Pada tanggal 13 April 2020 berdasarkan data Worldometers (diambil dari Rossa \& Putri, 2020), jumlah kasus dari virus ini di dunia sudah mencapai angka 1.856 .800 pasien yang positif corona sedangkan angka kematian pasien positif COVID-19 secara global telah menyentuh angka 114.312 jiwa dan pasien yang berhasil sembuh 428.275 orang.(Radhitya, Nurwati, \& Irfan, 2020).

Menurut Abidah (Putra, Liriwati, \& Tahrim, 2020) ketidakhadiran siswa di ruang kelas akibat kebijakan nasional belajar dari rumah karena alasan virus corona, hal ini memang perlu kajian khusus untuk memastikan apakah sekolah juga bisa menjadi tempat penyebaran virus seperti kasus penyebaran normal di suatu negara. kerumunan di luar. Seharusnya ada lebih banyak penelitian yang menyelidiki masalah seperti itu selama penutupan sekolah untuk memahami bagaimana virus menyebar di lingkungan sekolah. Sedangkan Kurnia (Ulpi, Hakim, Kadir, Pajarianto, \& Rahmatia, 2021) selain China Negara Indonesia juga terdampak sejak februari 2020 yang hingga sekarang, yang mengakibatkan banyaknya aktivitas masyarakat tidak normal seperti sebelumnya. Salah satu cara untuk menghentikan penyebaran COVID-19 yaitu dengan membatasi aktivititas sosial dan melakukan karantina kepada orang-orang yang terjangkit. Indonesia sudah mengalami kondisi dimana kekhawatiran masyarakat terhadap COVID-19 cukup besar, sehingga diperlukan kebijakan pemerintah untuk melakukan lockdown, sebagai upaya memutus mata rantai penyebaran virus COVID-19. Menurut Valerisha \& Putra (Sakti, 2021) negara-negara berkembang cukup kesulitan menerapkan protokol kesehatan sesuai standar WHO karena sarana dan prasarana yang belum memungkinkan. Di awal pandemi Covid-19, anak-anak disebut sebagai kelompok usia yang relatif tidak rentan terkena virus corona ini. Meskipun demikian, Ikatan Dokter Anak Indonesia (IDAI) mengemukakan fakta bahwa tingkat penularan virus corona pada anak-anak di Indonesia tergolong cukup tinggi sehingga harus membuat orangtua waspada.

Dalam rangka pemenuhan hak peserta didik untuk mendapatkan layanan pendidikan selama darurat penyebaran Corona Virus Disease (COVID-19), maka penyelenggaraan belajar dilakukan dari rumah. Sekolah diberikan kebebasan dalam mengelola kegiatan belajar mengajar melalui sarana Dalam Jaringan (Daring). Para guru memberikan pelajaran yang lebih bermakna agar siswa tetap merasa nyaman dan produktif mengasah soft skills. Sekolah juga berinisiatif membuat poster-poster anjuran belajar dari rumah untuk memberikan pemahaman kepada siswa dan orang tua, terutama bagi siswa tingkat dasar. Hal ini bertujuan agar siswa tetap melaksanakan proses belajar mengajar meskipun tidak berada di sekolah.(Nadeak \& Juwita, 2020).

Dengan demikian (Besand, 2020, Besand dan Mulyanti Mulyanti, Purnama, \& Pawinanto, 2020) konteks ini, pandemi Covid-19 menawarkan kesempatan belajar yang tidak terduga dan sangat energik terlihat dan kesempatan belajar teknis. Namun, upaya ini sedang ditantang oleh situasi yang belum pernah terjadi sebelumnya seperti aturan jarak sosial di mana sekolah dan kantor ditutup untuk mengekang infeksi virus. Selanjutnya Menteri Pendidikan dan Kebudayaan Nadiem Makarim mengeluarkan kebijakan yang dituangkan dalam Surat Edaran No.4 / 2020 pada 24 Maret 2020.

Berdasarkan dari beberapa teori di atas bahwa belum semua sarana prasarana sekolah di Indonesia khususnya di daerah perbatasan terutama pada akses internet dalam proses pembelajaran melalui daring, sejatinya hal ini yang menjadi kendala dalam proses pembelajaran terhadap siswa di daerah yang minim dengan akses internet. Selain itu juga diperparah lagi tidak adanya alat atau perangkat yang dimiliki oleh setiap siswa seperti laptop/nootbook, dan smartphone. Hal ini diperkuat oleh beberapa teori dari (Sadikin \& 
Hamidah, 2020) guru mengalami kesulitan sinyal selular ketika di daerah masing-masing, jikapun ada sinyal yang didapatkan sangat lemah. Pembelajaran daring memiliki kelemahan ketika layanan internet lemah, dan intruksi guru yang kurang dipahami. Tantang lain yang dihadapi adalah kendala dalam pembiayaan pembelajaran daring. Anak mengungkapkan bahwa untuk mengikuti pembelajaran daring, mereka harus mengeluarkan biaya cukup mahal untuk membeli kuota data internet. Menurut Fujiawati (Asmawati, 2021) pemanfaatan media teknologi dalam pembelajaran daring oleh guru PAUD diantaranya whatsapp, google meet, zoom, video call, media social, siaran televisi, dan buku tema sekolah. Dari sekian banyak aplikasi, whatsapp menjadi platform yang sering digunakan dan cukup membantu pelaksanaan pembelajaran anak di rumah. Studi terdahulu memberikan kesimpulan bahwa pemanfaatan teknologi dalam pembelajaran PAUD memberikan rangsangan dan membangkitkan semangat peserta didik.

Hal ini menjadi tanggung jawab guru PAUD bahwa proses pembelajaran di lembaga PAUD pada umumnya dilakukan melalui tatap muka secara langsung di dalam kelas. Hal ini karena dalam proses pembelajaran anak usia dini masih membutuhkan bimbingan guru secara langsung, karena guru merupakan pelaksana sekaligus pemandu jalannya proses pembelajaran di dalam kelas.(Larimore, 2020). Dirjen PAUD Dikdasmen Kemendikbud, Harris Iskandar menjelaskan bahwa guru tidak harus terpaku pada pembelajaran daring dan pemberian tugas (CNN Indonesia.com, 31 Maret 2020). Walaupun pembelajaran dilakukan secara daring/online, guru diharapkan dapat mengembangkan kreativitas dan inovasi dalam memberikan pembelajaran yang menyenangkan melalui media teknologi.(Srihartini et al., 2020). Pembelajaran daring merupakan pembelajaran yang dilakukan tanpa melakukan tatap muka, tetapi melalui platform yang telah tersedia. Segala bentuk materi pelajaran didistribusikan secara online, komunikasi juga dilakukan secara online, dan tes juga dilaksanakan secara online. Sistem pembelajaran melalui daring ini dibantu dengan beberapa aplikasi, seperti Google Classroom, Google Meet, Edmudo dan Zoom (Pratama \& Mulyati, 2020). Dalam Ebi (Asmawati, 2021) pembelajaran daring di masa pandemic mengharuskan dua pihak (pendidik dan orang tua) untuk bekerja sama. Orang tua juga memiliki peran khusus dalam pelaksanaan kebijakan ini. Pada era digital, keluarga harus tetap mempertahankan dimensi fisik, tatap muka, dan menjalin proses komunikasi yang harmonis.

Adanya kendala-kendala di masa pandemic Covid-19 menjadi tantangan bagi sekolah dalam mengelola lembaga sekolah. Dengan demikian diperlukan tatanan pengelolaan pembelajaran oleh guru PAUD. Tujuan penelitian ini untuk mengetahui bagaimana upaya yang dilakukan guru dalam menajaga tata kelola pembelajaran pada pendidikan anak usia dini di masa pandemic COVID-19. Tata kelola pembelajaran diantaranya perncanaan, pelaksanaan dan penilaian. Guru sebagai pendidik diharapkan hasil dari penelitian ini dapat menginspirasi seluruh jenjang pendidikan dalam mengelola sekolah agar kendala-kendala dalam pembelajaran daring dapat teratasi oleh guru PAUD.

\section{METODOLOGI}

Metode penelitian yang digunakan dalam penelitian ini adalah metode kualitatif deskriptif dengan menggunakan pendekatan studi kasus. Dengan studi kasus dapat menjawab satu ataupun lebih pertanyaan how dan why (Prima, Sya, Nur, \& Sya, 2019). Metode ini dipilih karena peneliti ingin mengidentifikasi guru melalui hasil wawancara guru terhadap pemanfaatan teknologi serta upaya guru dalam memanfaatkan teknologi tersebut. Dengan begitu, metode deskriptif ini dirasa sangatlah cocok untuk digunakan dan sejalan dengan fungsi dari penelitian ini yakni untuk mengumpulkan dan menjelaskan opini atau pendapat dari sekelompok orang (sampel penelitian) terhadap topic tertentu. Subjek yang digunakan pada penelitian ini adalah guru tiap dari lembaga sekolah yang berjumlah 18 guru di Kota Surabaya penentuan subjek berdasarkan pemilihan sekolah Taman Kanak-kanak yang hanya terakreditasi A. Teknik pengumpulan data berupa wawancara melalui whatsapp. Wawancara bertujuan untuk menggali lebih dalam akan fenomena yang akan diteliti (Yona, 2014). 
Wawancara yang dilakukan meliputi bagaimana perencanaan, pelaksanaan, dan penilaian. Analisis data akan di coding dan dideskripsikan secara narasi menggunakan koleksi data, reduksi data, penyajian data, penarikan kesimpulan. Gambaran desain penelitian dapat dilihat pada gambar 1 .

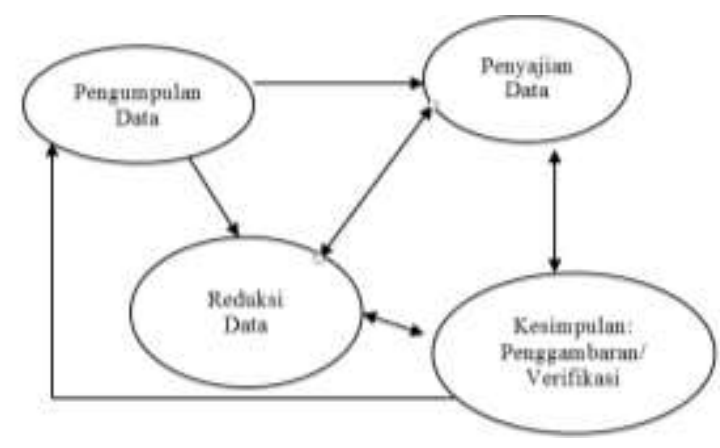

Gambar 1. Desain penelitian

\section{HASIL DAN PEMBAHASAN}

Kondisi saat ini memang menjadi sebuah tantangan bagi seluruh jenjang pendidikan dalam menjaga tata kelola pembelajaran sekolah yang belum terfikirkan sebelumnya. Seperti yang telah dikeluarkan surat edaran kebijakan Pelaksanaan Pendidikan Dalam Masa Darurat COVID-19 Nomor 4 Tahun 2020 bahwa seluruh proses belajar mengajar dan pendidikan harus di lakukan secara daring. Kondisi ini memaksa seluruh warga sekolah melaksanakan kegiatan belajar menagajar secara daring mulai dari pembelajaran dan seluruh layanan sekolah bagi wali murid maupun guru. Penelitian ini memiliki 18 responden yang mana mengambil masing-masing responden guru TK di Kota Surabaya yang memiliki akreditasi sekolah A sesuai deangan data BAN PAUD-PNF. berikut hasil penjabaran penelitian secara spesifik yang dilakukan kepala sekolah dalam menjaga tata kelola sekolah pendidikan anak usia dini selama pandemi covid-19.

\section{Tata Kelola Perencanaan pada Masa Pandemi Covid-19}

Dari semua kegiatan sejatinya di awali oleh perencanaan. Perencanaan sendiri memerlukan kematangan sebelum dilaksanakan kegiatanya. Tidak terkecuali pembelajaran yang sangat penting untuk dilakukan perencanaan terlbih dahulu guna tercapainya tujuan. Perencanaan pembelajaran sendiri adalah setiap kegiatan yang dibuat oleh guru untuk melaksanakan kegiatan belajar mengajar dan setiap kegiatanya di utamakan tujuan pembelajaran yang ingin dicapai bagaimana isi materi yang sesuai kemudian penggunaan metode yang disesuaikan usia anak dalam mencapai perkembanganya, dan melakukan evaluasi untuk mengetahui ketercapaian berhasil tidaknya kegiatan yang telah direncanakan.

Berdasarkan hasil penelitian bahwa dari 18 responden memiliki perencanaan yang matang dalam membuat perencanaan pembelajaran. Salah satunya adalah seluruh jenis-jenis perencanaan yang dibuat mulai dari perencanaan tahunan, perencanaan semester, perencanaan mingguan, dan perencanaan harian. Menurut Permendikbud 146 Tahun 2014 dalam pengembangan rencana pembelajaran dinyatakan bahwa perencanaan pembelajaran anak usia dini meliputi perencanaan semester, rencana kegiatan mingguan (RKM), dan rencana kegiatan harian (RKH). Menurut (Kebudayaan, 2012) Kurikulum Darurat adalah kurikulum tingkat satuan pendidikan yang disusun dan dilaksanakan oleh satuan pendidikan pada masa darurat dengan memperhatikan rambu-rambu ketentuan yang berlaku serta kondisi keterbatasan masing-masing satuan pendidikan dimasa darurat. Hal ini sudah terbukti dari hasil penelitian bahwa perencanaan dalam tata kelola pembelajaran sudah dilaksanakan sesuai dengan situasi da kondisi pada saat sekarang sehingga guru banyak membuat program perencanaan yang fleksibel. 
Rencana Pelaksanaan Pembelajaran Mingguan (RPPM) merupakan rencana kegiatan yang disusun untuk pembelajaran selama satu minggu. Perencanaan kegiatan mingguan dapat berbentuk jaringan tema. Jaringan tema berisi projek-projek yang akan dikembangkan menjadi kegiatan-kegiatan pembelajaran. Cara penyusunan RPPM diturunkan dari program semester (prosem) yang berisi sub tema, KD, materi, rencana kegiatan. RPPM dikembangkan dari kegiatan semester, namun penyajiaannya lebih lengkap dan lebih operasional. Dalam program mingguan sudah diidentifikasi tema dan sub tema, pemetaan kompetensi dasar dan indikator yang akan dicapai dalam satu minggu, dan muatan materi yang akan dibangun oleh peserta didik serta sejumlah aktivitas bermain sesuai dengan tema dan indikator yang akan dicapai serta penetapan media, alat dan bahan yang akan digunakan.Penyusunan kegiatan mingguan disesuaikan dengan strategi pengelolaan kelas (area, sentra, kelompok usia) yang ditetapkan masingmasing satuan PAUD. Rencana pelaksanaan pembelajaran tingkat satuaan PAUD bersifat fleksibel dan disesuaikan dengan lingkungan belajar anak itu sendiri. Jadi jikapun diadakan pembelajaran jarak jauh tetap dapat dilakukan pembelajaraan sesuai dengan hasil yang diharapkan meskipun standart tingkat penilaiannya berbeda dengan belajar di sekolah.

Selain itu kuota internet, Rencana Pelaksanaan Pembelajaran Harian (RPPH), mengkomunikasikan kepada orang tua bahwa pembelajaran dilaksanakan secara daring, alat tulis yang disiapkan di rumah, handphone android, lembar kerja anak, materi yang akan dibagikan kepada orang tua. Terdapat salah satu sekolah TK yang membuat pembelajaran melalui video tutorial kegiatan yang akan dilakukan oleh anak. Hal ini sejalan dengan Sukardi \& Rozi (Ayuni, Marini, Fauziddin, \& Pahrul, 2020) bahwa pembelajaran online bisa dilakukan melalui video tutorial yang bisa diakses melalui media sosial salah satunya youtube. Video tersebut dibuat sesuai dengan tema-tema pembelajaran. Tujuan pembuatan video tutorial tersebut adalah agar anak tetap melihat guru yang mengajar. Video tersebut dibuat secara singkat dan jelas. Video tutorial tersebut dibagikan kepada orang tua atau bisa diakses melalui halaman youtube.

Berdasarkan dari hasil seluruh 18 responden bahwa perencanan dilakukan mengikuti sesuai dengan anjuran dari dinas pendidikan Kota Surabaya yang mana rencana pelaksanaan pembelajaran dilakukan secara online melalui SIMPAUD hanya menjadi satu lembar saja yakni hanya berupa rencana kegiatan mingguan (RKM). Sesuai dengan anjuran Penyusunan pelaksanaan pembelajaran ini disesuaikan dengan format penyusunan baru yang telah dikeluarkan oleh Menteri Pendidikan dan Kebudayaan Surat Edaran No. 14 Tahun 2019 yang mana tidak memberatkan guru di mana penyusunan rencana pelaksanaan pembelajaran dilakukan dengan prinsip efisien, efektif, dan berorientasi pada murid. Format penyusunanya berupa tujuan pembelajaran, kegiatan pembelajaran dan penialaian. Menurut Mendikbud dikutip pada kemendikbud.go.id (11/12/2019) bahwa rencana pelaksanaan pembelajaran cukup diringkas menjadi satu halaman saja.

Sebelum melakukan proses pembelajaran, guru harus merancang pembelajaran dengan mengembangkan kurikulum yang ada. Guru adalah pendidik profesional yang bertanggung jawab untuk mengembangkan perencanaan pembelajaran yang dapat mengembangkan seluruh potensi anak. Perencanaan pembelajaran yang dibuat oleh guru dimaksudkan agar tujuan yang sdudah ditetapkan dapat tercapai (Apriyanti, 2017). Situasi dan kondisi pasca pandemi Covid-19 ternyata tidak menyurutkan semangat para pendidik PAUD baik formal maupun nonformal untuk tetap membuat perencaanan pembelajaran. Dengan segala keterbatasan yang ada, pendidik membuat rencana pembelajaran agar membantu orang tua saat mendampingi putra -putrinya belajar di rumah. Pendidik juga berupaya melakukan inovasi-inovasi pembelajaran agar peserta didik tidak merasa bosan. Hal ini sesuai dengan hasil penelitian Primayana (2019) yang menekankan inovasi dalam perencanaan pembelajaran agar bisa memenuhi harapan dan tantangan dari era revolusi 4.0.

Guru melalui SIMPAUD hanya tinggal mengisi kegiatan selama satu minggu yang tetap disesuaikan dengan Kompetensi Inti dan Kompetensi Dasar yang telah tertera dalam 
aplikasi dan guru tinggal menyesuaikan dengan kegiatan selama satu minggu. Kegiatan dalam satu minggu ini menurut responden tetap disesuaikan dengan kebutuhan perkembangan anak yakni sesuai dengan enam aspek perkembanganya. Kemudian output yang di hasilkan dari aplikasi ini adalah sebuah print out satu lembar RKM yang kemudian harus diberikan tanda tangan guru wali kelas dan kepala sekolah, kemudia di upload ulang melalui SIMPAUD dan akan di periksa secara online oleh penilik apakah RKM telah sesuai atau belum.

\section{Tata Kelola Pelaksanaan pada Masa Pandemi Covid-19}

Pelaksanaan dalam proses daring dengan 18 responden menyatakan bahwa menggunakan aplikasi seperti zoom, whatapp, google meet, pengambilan tugas menggunakan system drive thru yang saat ini banyak digunakan di sekolah-sekolah. Pelaksanaan proses pembelajaran PAUD di masa pasca pandemi Covid-19 memang disesuaikan dengan kondisi setiap lembaga dan keluarga/rumah semua peserta didik. Beberapa lembaga PAUD tetap sepenuhnya melakukan pembelajaran daring, namum ada juga lembaga PAUD yang menggabungkan dua metode yaitu daring dan luring. Penggabungan dua metode ini lebih dikenal sebagai pembelajaran blended learning. Anak usia dini memang lebih membutuhkan interaksi langsung secara fisik/tatap muka agar dapat membentuk ikatan emosional pendidik dan peserta didik. Penggunaan metode pembelajaran yang hanya daring menimbulkan kurangnya ikatan emosional ini, sehingga terkadang ditemukan peserta didik yang enggan melakukan tugas-tugas belajar yang sudah direncanakan oleh pendidik. Kebosanan anak lebih besar lagi dengan tidak adanya temanteman sekolah yang biasa bermain dan belajar bersama. Selain itu beban orang tua yang karena tuntutan ekonomi harus banyak keluar rumah bekerja mencari nafkah juga menjadi faktor yang semakin membuat anak rindu sekolah.(Taulany, 2020). Sedangkan pelaksanaan blended learning ini ada beberapa hal yang harus diperhatikan oleh pengajar, yaitu aturan main terkait protokol kesehatan, bahasa yang digunakan ketika terjadi pelanggaran protokol kesehatan, social inclusion bagi anak yang pernah terdampak Covid-19, mekanisme, mekanisme absensi, penggunaan fasilitas bersama, isu penguasaan teknologi yang kurang, dan higienitas fasilitas. Salah satu yang kurang menjadi perhatian di Indonesia, adalah penggunaan bahasa di kelas ketika menegur anak.(Nurlina \& Wulandari, 2015).

Berdasarkan hasil penelitian pelaksanaan yang dilaksanakan oleh guru TK di Kota Surabaya dilakukan secara metode blended learning yaitu secara daring dan luring dan visit home yang dilakukan oleh guru yang berkerjasama dengan orang tua di rumah dengan menggunakan protokol kesehatan. Pelaksanaan ini dilaksanakan 1 minggu dalam 3 hari dengan berkelompok yang sudah dirancang oleh guru TK. Tata kelola yang dilaksanakan oleh guru TK tersebut sudah memberikan kesan yang baik dalam proses pembelajaran bagi anak TK serta orang tua rumah juga merasa terbantu.

Kebijakan belajar di rumah, membuat para guru, termasuk di jenjang PAUD, diharapkana beradaptasi. Pembelajaran segera yang biasanya dilakukan tatap muka di sekolah, kini harus dilakukan belajar secara jarak jauh dengan mempergunakan teknologi komunikasi. Dengan platform pembelajaran yang baru para guru PAUD harus memiliki kemampuan dan keterampilan mengoperasikan teknologi tersebut, merencankan pembelajaran jarak jauh yang menyenangkan yang masih sesuai dengan kurikulum pendidikan (Nurlina \& Wulandari, 2015). Selain itu menurut Dariyatun (2021) kegiatan proses pembelajaran pada anak usia dini pada dasarnya adalah pengembangan kurikulum secara konkrit berupa seperangkat rencana yang berisi sejumlah pengalaman belajar melalui bermain yang diberikan kepada anak usia dini berdasarkan potensi dan tugas perkembangan yang dikuasainya dalam rangka pencapaian kompetensi yang harus dimiliki anak. Kondisi pandemi Covid-19 memang tidak dapat dihindari karena sudah menjadi bencana yang merata di hampir semua belahan dunia. Diperlukan sikap dan pola pikir optimis dan solutif agar 
keberlangsungan kehidupan termasuk proses pembelajaran bagi anak usia dini dapat tetap berlangsung.

Untuk melakukan pembelajaran via online dalam pembelajaran jarak jauh guru juga harus mempertimbangkan tentang kemampuan orang tua/wali murid peserta didik, yang mana sebagian besar wali murid/orang tua peserta didik yang merasa tidak sanggup untuk mengajari pembelajaran putra-putrinya meskipun itu pembelajaran awal atau tahap PAUD. Maka dari itu setiap kegiatan yang diberikan kepada peserta didik setiap harinya guru juga memberikan tutorial melalui video atau jika untuk melafalkan dan menghafalkan doa harian, hadist, surat pendek, dan fasholatan guru memberikan voicenote yang mana dapat diputar dan di pelajari oleh peserta didik meskipun hanya belajar di rumah saja. Dan video tutorial atau voicenote guru di bagikan melalui grup whatsapp yang telah dibentuk sesuai dengan rombel dan guru wali kelas masing-masing.

\section{Tata Kelola Evaluasi Pembelajaran pada Masa Pandemi Covid-19}

Penilaian atau Evaluasi kinerja guru merupakan suatu proses yang menentukan apakah tujuan dari pendidikan anak usia dini sudah terpenuhi atau belum. Guru dinilai berdasarkan kemampuan mereka untuk menerapkan tujuan pendidikan. Anggota staf pendukung dinilai berdasarkan kemampuan mereka untuk melakukan pekerjaan mereka dengan cara yang melengkapi fungsi pendidikan.(Dewi \& Suryana, 2020). Evaluasi adalah suatu proses menafsirkan berbagai informasi secara sistematis, berkala, berkelanjutan, dan menyeluruh tentang proses dan hasil dari pertumbuhan serta perkembangan yang telah dicapai oleh anak mellaui kegiatan pembelajaran dan menginterpretasikan informasi tersebut untuk membuat keputusan. Berdasarkan dari hasil penelitian yang ada di TK Kota Surabaya dalam tata kelola evaluasi pembelajaran di di sekolah menurut dari salah satu guru "sebagian besar penilaian disalin dari nilai semester sebelumnya. Sebagian lagi dengan mengolah input nilai setengah semester yang telah berlangsung kemudian terhenti. Serta sebagian kecil lagi mengolah nilai sebelum pandemi dan beberapa pertemuan daring yang sempat terjadi. Alhasil, penilaian yang tidak menuntut penuntasan kurikulum memposisikan peserta didik tanpa melakukan pembelajaran pun dalam posisi aman".

Tata kelola penerapan evaluasi pembelajaran AUD sifatnya dimodifikasi dari model yang sebelumnya sudah ada. Hasil temuan penelitian diantaranya; evaluasi pembelajaran berbasis portofolio pada saat pandemi covid-19 memang sudah digunakan, hanya saja pada saat munculnya pandemi covid-19 menjadi lebih sering di gunakan. Model evaluasi ini berbentuk pengumpulan tugas-tugas pekerjaan rumah siswa yang lalu di kumpulkan menjadi satu menjadi portofolio. Setiap satu bulan sekali para guru meminta siswa untuk mendokumentasikan semua tugas-tugas yang telah mereka kerjakan, dan lantas di kumpul dalam satu wadah berupa map atau sejenisnya, maka hal ini lah yang dianggap seperti portfolio oleh gurunya. Model evaluasi ini memang terbilang cukup ampuh untuk mengatasi kesulitan dalam menentukan bentuk evaluasi pembelajaran. Jika ujian dilakukan secara tes, bukan tidak memungkinkan bagi siswa melakukan kecurangan- kecurangan. Namun dalam hal portofolio, siswa dapat meminta bantuan orang tuannya mendampingi proses pengerjaan tugas-tugas yang ada. Dalam hal ini selain berfungsi untuk mengukur aspek kognitif siswa, kegiatan evaluasi portofolio juga berfungsi untuk mengukur aspek psikomotorik, dan bahkan menilai aspek afektif, seperti kedisiplinan dalam pengerjaan tugas, kerapian dokumentasi fortofolio dan sebagainya.

Puckett \& Black (Setiawati, 2018) menyebutkan evaluasi portfolio adalah satu metode evaluasi dengan mengumpulkan dan mengorganisasi hasil karya siswa dan mengevaluasinya dalam mempertunjukkan upaya, kemajuan dan pencapaian yang diperoleh anak didik dalam satu atau beberapa bidang belajaranya (Lebih lanjut benjelaskan adanya beberapa syarat tertentu dalam mengoleksi karya anak didik adalah melibatkan partisipasi anak didik dalam : 1) menyeleksi isi, 2) menentukan criteria seleksinya, kriteria kemanfaatanya, dan 
kebermaknaanya, 3) sebagai bukti refleksi diri anak didik atas apa yang telah dilakukan dan pendidik hanya menolong seperlunaya.

Tata kelola evalasui berbasis praktik ini lebih kepada motrotik kasar, halus. Menurut hasil wawancara oleh guru di TK Surabaya bahwa "masa pandemi ini evaluasi di modifikasi untuk keterampilan berbasis sosial, emosional, dan juga kecerdasan kognitif. Seperti hasil penelitian terdapat beberapa jenis penugasan diantaranya bermain ular tangga, bermain melompati tali, bermain mengumpulkan benda-benda ada di rumah, bermain bernyanyi dan sebagainya.

\section{SIMPULAN}

Transformasi pembelajaran masa pandemi covid-19 diperlukan tata kelola dalam proses pembelajaran bagi guru supaya mendapatkan hasil yang baik bagi anak. Tata kelola dalam pembelajaran dengan menggunakan kurikulum darurat artinya direncanakan secara fleksibelitas sesuai dengan zona (situasi dan kondisi lingkungan) dengan membuat kegiatan harian, mingguan, bulanan dan tahunan yang dirancang secara khusus pada masa pandemi Covid-19. Tata kelola pelaksanaan menggunakan dua metode yaitu daring dan luring. Penggabungan dua metode dikenal sebagai pembelajaran blended learning, memberikan kontribusi yang baik bagi guru dalam melaksanakan pembelajaran. Evaluasi pembelajaran masa pandemi covid-19 diantaranya evaluasi berbasis portofolio dengan tujuan memberikan tugas yang dibantu oleh orang tua.

\section{UCAPAN TERIMA KASIH}

Penulis ucapkan terimakasih kepada semua pihak yang telah membantu penulis terutama kepada pembimbing Prof. Dr. Siti Masitoh, M.Pd dan Dr. Sri Setyowati, M.Pd yang sudah membantu peneliti dalam menyempurnakan hasil penelitian ini. Ucapan terimkasih juga disampaikan kepada tim editor Jurnal Obsesi yang telah memberikan saran, kritik dan rekomendasi untuk perbaikan

\section{DAFTAR PUSTAKA}

Asmawati, L. (2021). Peran Orang Tua dalam Pemanfaatan Teknologi Digital pada Anak Usia Dini. Jurnal Obsesi: Jurnal Pendidikan Anak Usia Dini, 6(1), 82-96. https:// doi.org/10.31004/obsesi.v6i1.1170

Ayuni, D., Marini, T., Fauziddin, M., \& Pahrul, Y. (2020). Kesiapan Guru TK Menghadapi Pembelajaran Daring Masa Pandemi Covid-19. Jurnal Obsesi : Jurnal Pendidikan Anak Usia Dini, 5(1), 414. https:// doi.org/10.31004/obsesi.v5i1.579

Besand, A. (2020). The crisis as an opportunity to learn. Or: 'collateral civic education' in the context of the covid-19 pandemic an essay in times of crises. Journal of Social Science Education, 19(Special Issue 1), 8-14. https:/ / doi.org/10.4119/jsse-3488

Dariyatun, D. (2021). Menjaga Mutu Pendidikan PAUD pada Masa Pandemi Covid-19 dengan Pembelajaran Jarak Jauh ( PJJ ). Korwil Dindikpora, 9(1), 58-64.

Dewi, I., \& Suryana, D. (2020). Analisis Evaluasi Kinerja Pendidik Pendidikan Anak Usia Dini di PAUD Al Azhar Bukittinggi. Jurnal Obsesi : Jurnal Pendidikan Anak Usia Dini, 4(2), 1051. https://doi.org/10.31004/obsesi.v4i2.465

Kebudayaan, K. P. dan. (2012). Konsep Dasar Pendidikan Anak Usia (Direktorat jenderal Pendidikan Anak Usia Dini Non Formal Informal. Semarang: P2PNFI Regional II Semarang).

Larimore, R. A. (2020). Preschool Science Education: A Vision for the Future. https://doi.org/.(Early Childhood Education Journal, 2020) dinduh https://doi.org/10.1007/s10643-020-01033-9

Mulyanti, B., Purnama, W., \& Pawinanto, R. E. (2020). Distance learning in vocational high schools during the covid-19 pandemic in West Java province, Indonesia. Indonesian 
Journal of Science and Technology, 5(2), 271-282. https://doi.org/10.17509/ijost.v5i2.24640

Nadeak, B., \& Juwita, C. P. (2020). Kepemimpinan kepala sekolah dalam menjaga tata kelola sekolah selama masa pandemi Covid-19. Jurnal Konseling Dan Pendidikan, 8(3), 207. https://doi.org/10.29210/149400

Nurlina, \& Wulandari, A. (2015). Pelaksanaan Pembelajaran Daring Pada Masa Pendemi di TK Aisyiyah Bustanul Alhfat 1. PAUD.

Pratama, R. E., \& Mulyati, S. (2020). Pembelajaran Daring dan Luring pada Masa Pandemi Covid-19. Gagasan Pendidikan Indonesia, 49. https://doi.org/10.30870/gpi.v1i2.9405

Prima, R., Sya, D., Nur, S., \& Sya, H. (2019). Metode Study Kasus. Sekolah Tinggi Agama Islam Negeri (STAIN) Sorong, 19.

Putra, P., Liriwati, F. Y., \& Tahrim, T. (2020). The Students Learning from Home Experience during Covid-19 School Closures Policy in Indonesia. Jurnal Iqra': Kajian Ilmu Pendidikan, 5(2), 30-42. https://doi.org/10.25217/ji.v5i2.1019

Radhitya, T. V., Nurwati, N., \& Irfan, M. (2020). Dampak Pandemi COVID-19 Terhadap Kekerasan dalam Rumah Tangga. Jurnal Kolaborasi Resolusi Konflik, 2(2), 111. https://doi.org/10.24198/jkrk.v2i2.29119

Sadikin, A., \& Hamidah, A. (2020). Pembelajaran Daring di Tengah Wabah Covid-19. Biodik, 6(2), 109-119. https://doi.org/10.22437/bio.v6i2.9759

Sakti, S. A. (2021). Persepsi Orang Tua Siswa terhadap Pembelajaran Daring pada Masa Pandemi Covid 19 di Yogyakarta. Jurnal Obsesi : Jurnal Pendidikan Anak Usia Dini, 6(1), 73-81. https://doi.org/10.31004/obsesi.v6i1.804

Setiawati, F. A. (2018). Implementasi Evaluasi Portfolio Abstrak. 1(1).

Srihartini, Y., Pratami, M., Fakultas, L., Iai, T., Laa, N., \& Bogor, R. (2020). Pembelajaran Pendidikan Anak Usia Dini Online di Era Pandemi Covid-19. TARBIATUNA Journal of Islamic Education $1 \mid$ Tarbiatuna, 1(1), 1-21. Retrieved from http://journal.laaroiba.ac.id/index.php/tarbiatuna/article/view/219

Taulany, H. (2020). Manajemen Proses Pembelajaran Pendidikan Anak Usia Dini. Prosiding Seminar Nasional Pascasarjana Unnes, 150-157. Retrieved from https://proceeding.unnes.ac.id/index.php/snpasca/article/view/565/484

Ulpi, W., Hakim, N., Kadir, A., Pajarianto, H., \& Rahmatia, R. (2021). Gambaran Kebugaran Jasmani Anak Usia Dini pada Masa Pandemi Covid-19. Jurnal Obsesi: Jurnal Pendidikan Anak Usia Dini, 6(1), 30-39. https:// doi.org/10.31004/obsesi.v6i1.1197

Yona, S. (2014). Penyusunan Studi Kasus. Jurnal Keperawatan Indonesia, 10(2), 76-80. https://doi.org/10.7454/jki.v10i2.177 